\title{
Analysis of endocrine activity in drinking water, surface water and treated wastewater from
}

\section{six countries}

Frederic D.L. Leusch ${ }^{\mathrm{a}^{*}}$, Peta A. Neale ${ }^{\mathrm{a}}$, Charlotte Arnal ${ }^{\mathrm{b}}$, Natalie H. Aneck-Hahn ${ }^{\mathrm{c}}$, Patrick

Balaguer $^{\mathrm{d}}$, Auguste Bruchet ${ }^{\mathrm{e}}$, Beate I. Escher ${ }^{\mathrm{a}, \mathrm{f,g}}$, Mar Esperanza $^{\mathrm{e}}$, Marina Grimaldi ${ }^{\mathrm{d}}$, Gaela Leroy ${ }^{\mathrm{b}}$, Marco Scheurer $^{\mathrm{h}}$, Rita Schlichting ${ }^{\mathrm{f}}$, Merijn Schriks ${ }^{\mathrm{i}, \mathrm{j}}$ and Armelle Hebert ${ }^{\mathrm{b}}$

${ }^{a}$ Australian Rivers Institute, School of Environment and Science, Griffith University, Southport QLD 4222, Australia

${ }^{\mathrm{b}}$ Veolia Research \& Innovation, 78600 Maisons-Laffitte, France

${ }^{c}$ Environmental Chemical Pollution and Health Research Unit, Faculty of Health Sciences, University of Pretoria,

Pretoria, South Africa

${ }^{\mathrm{d}}$ Institut de Recherche en Cancérologie de Montpellier, INSERM/Université de Montpellier, 34298 Montpellier, France

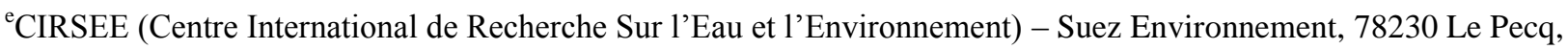

France

${ }^{\mathrm{f}} \mathrm{UFZ}$ - Helmholtz Centre for Environmental Research, 04318 Leipzig, Germany

${ }^{\mathrm{g}}$ Eberhard Karls University Tübingen, Environmental Toxicology, Center for Applied Geosciences, 72074 Tübingen,

Germany

${ }^{\mathrm{h}}$ DVGW - Technologiezentrum Wasser, Karlsruher Str.84, 76139 Karlsruhe, Germany

${ }^{\mathrm{i}}$ KWR Watercycle Research Institute, 3433 PE, Nieuwegein, The Netherlands

${ }^{\mathrm{j}}$ Vitens drinking water company, 8019 BE, Zwolle, The Netherlands

*corresponding author: f.leusch@ @riffith.edu.au; Ph: +61 (0)7 55527832

\section{Highlights}

- Wastewater, surface water and drinking water grab samples from 6 countries analysed.

- Applied bioassays for 7 endocrine pathways in agonist and antagonist mode.

- Endocrine activity only above LOQ in two wastewater and two surface water samples.

- Estrogenic and glucocorticoid activity in wastewater may pose ecological risk.

- Lack of endocrine activity in drinking water indicates negligible risk to humans. 


\section{Abstract}

The aquatic environment can contain numerous micropollutants and there are concerns about endocrine activity in environmental waters and the potential impacts on human and ecosystem health. In this study a complementary chemical analysis and in vitro bioassay approach was applied to evaluate endocrine activity in treated wastewater, surface water and drinking water samples from six countries (Germany, Australia, France, South Africa, the Netherlands and Spain). The bioassay test battery included assays indicative of seven endocrine pathways, while 58 different chemicals, including pesticides, pharmaceuticals and industrial compounds, were analysed by targeted chemical analysis. Endocrine activity was below the limit of quantification for most water samples, with only two of six treated wastewater samples and two of six surface water samples exhibiting estrogenic, glucocorticoid, progestagenic and/or anti-mineralocorticoid activity above the limit quantification. Based on available effect-based trigger values (EBT) for estrogenic and glucocorticoid activity, some of the wastewater and surface water samples were found to exceed the EBT, suggesting these environmental waters may pose a potential risk to ecosystem health. In contrast, the lack of bioassay activity and low detected chemical concentrations in the drinking water samples do not suggest a risk to human endocrine health, with all samples below the relevant EBTs.

\section{Graphical abstract}

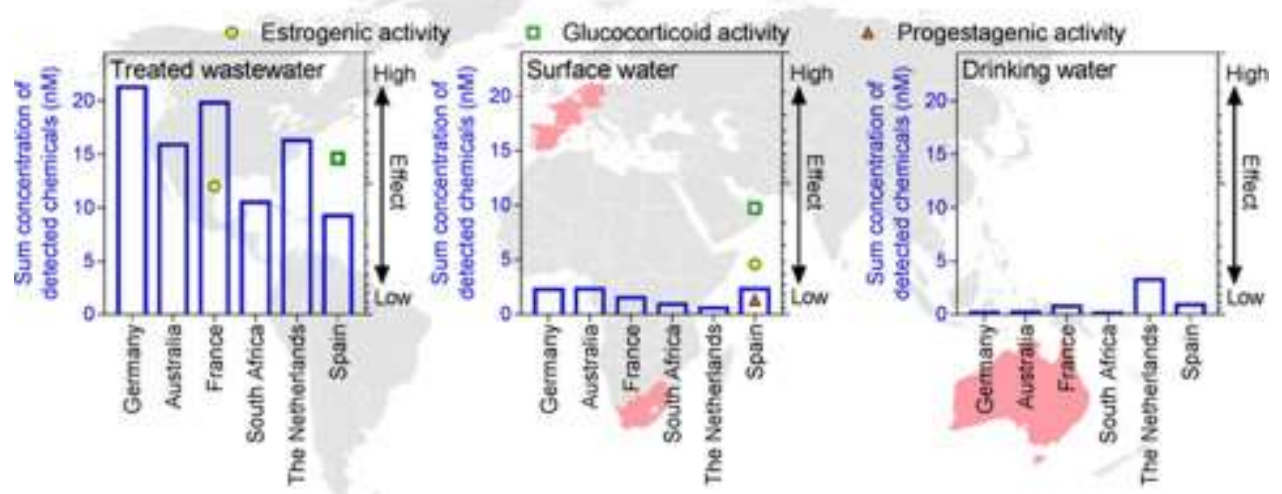

Keywords: bioassay; endocrine activity; environmental waters; in vitro; effect-based trigger value 


\section{Introduction}

The aquatic environment can contain a wide range of micropollutants, including pharmaceuticals, pesticides and industrial compounds, from sources such as wastewater effluent and agricultural runoff (Heeb et al., 2012; Eggen et al., 2014). The presence of micropollutants, including endocrine disrupting chemicals, in environmental waters can potentially have adverse effects on both human and ecological health (Bergman et al., 2013). For example, in the early 1990s estrogenic compounds in treated wastewater effluent were found to cause widespread endocrine disruption in fish in UK rivers (Purdom et al., 1994; Harries et al., 1996).

Targeted chemical analysis is commonly used to monitor micropollutant concentrations in water samples, but this approach alone has some limitations. For example, the aquatic environment can contain a complex mixture of micropollutants and their transformation products, often at low concentrations, and chemical analysis cannot account for the mixture effects that occur between these chemicals. For a more comprehensive assessment of water quality, chemical analysis can be complemented with in vitro bioassays. Bioassays can quantify the effect of all known and unknown chemicals active in a particular endpoint, account for mixture effects and are risk scaled, thus chemicals that are more potent will have a greater effect (Escher and Leusch, 2012; Wernersson et al., 2015). Due to concerns about the adverse effects of endocrine disrupting chemicals, in vitro bioassays indicative of hormonal activity have been applied to wastewater (e.g. Rutishauser et al., 2004; Bain et al., 2014; Suzuki et al., 2015), surface water (e.g. Chinathamby et al., 2013; Scott et al., 2014) and drinking water (e.g. Brand et al., 2013; Conley et al., 2017). A recent review found that the majority of studies to date focus on estrogenic activity, with much less known about progestagenic, glucocorticoid and thyroid activity in environmental waters (Leusch et al., 2017). However, a range of hormonal pathways is essential for growth, development and metabolism, so a more comprehensive assessment of endocrine activity in the aquatic environment is required.

To address this knowledge gap, the current study aimed to quantify endocrine activity in treated wastewater, surface water and drinking water collected from six countries (Germany, 
Australia, France, South Africa, the Netherlands and Spain) in order to assess the potential risks to ecological and human health. This was achieved using a comprehensive test battery of assays indicative of activation of the estrogen receptor (ER), androgen receptor (AR), glucocorticoid receptor (GR), progesterone receptor (PR), thyroid receptor (TR), retinoid X receptor (RXR), retinoid acid receptor (RAR) and mineralocorticoid receptor (MR). As some micropollutants can also act as antagonists (Sohoni and Sumpter, 1998; Ait-Aissa et al., 2010), assays indicative of inhibition of ER, AR, GR, PR, RXR, RAR and MR were also applied.

The bioassays were complemented with targeted chemical analysis of 58 micropollutants, including hormones, pharmaceuticals and personal care products, pesticides and industrial compounds. The endocrine activity detected in the current study was benchmarked against activity reported in previous studies and was also compared with available effect-based trigger values (EBT) to determine if the studied water samples posed a potential risk to human or ecological health.

\section{Materials and Methods}

\subsection{Water samples}

Grab samples of treated wastewater $(200 \mathrm{~mL})$, surface water $(1000 \mathrm{~mL})$ and drinking water $(2 \times 2000 \mathrm{~mL})$ were collected from six different countries (Germany, Australia, France, South Africa, the Netherlands, Spain). Ultrapure water or bottled mineral water was also included as a negative control $(1000 \mathrm{~mL})$. Further information about the collected samples, along with the sample ID numbers, can be found in Table S1 of the Supplementary Information (SI). A range of water quality parameters, including temperature, $\mathrm{pH}$, conductivity and total organic carbon, were measured for each water sample, with details provided in Table S2. The water samples were enriched by partners in each participating country using StrataX solid phase extraction (SPE) cartridges (200 mg, Phenomenex) following a harmonised protocol. Briefly, water samples adjusted to $\mathrm{pH} 2$ were added to conditioned SPE cartridges at a flow rate of approximately $7-10 \mathrm{~mL} / \mathrm{min}$. 
One cartridge was used for each water matrix, with the exception of drinking water where two cartridges were used (2000 mL per cartridge). After loading, the SPE cartridge was dried under a gentle nitrogen stream and then sent to DVGW - Technologiezentrum Wasser (TZW) in Germany for elution with $3 \mathrm{~mL}$ methanol, $3 \mathrm{~mL}$ acetonitrile and $3 \mathrm{~mL}$ acetone. All solvents were of analytical grade. The eluate was blown to dryness under a gentle nitrogen stream and reconstituted in $1 \mathrm{~mL}$ of methanol, giving enrichment factors of 200 (treated wastewater), 1000 (surface water) and 4000 (drinking water). The control ultrapure water also had an enrichment factor of 1000 . The extract was divided into $100 \mu \mathrm{L}$ aliquots and sent to all participating laboratories for chemical and bioassay analysis.

\subsection{Chemical analysis}

Four different chemical analysis methods were applied to detect micropollutants in the water extracts. Forty five micropollutants, including pharmaceuticals, hormones, pesticides and industrial compounds, were analysed using liquid chromatography - electrospray ionization - tandem mass spectrometry (LC-ESI-MS/MS; Table S4, while liquid chromatography - atmospheric pressure chemical ionization - high resolution mass spectrometry (LC-APCI-HRMS) was applied to detect five additional hormones, androsterone, cortisol, cortisone, epitestosterone and norethisterone (Table S5). Further, eleven semi-volatile micropollutants were detected using gas chromatography mass spectrometry (GC/MS; Table S6). In total, 58 different chemicals were analysed using these three methods. Further information about the applied methods can be found in Tables S3 to S6 of the SI, with the analytical limit of quantification $\left(\mathrm{LOQ}_{\mathrm{chem}}\right)$ in the different matrices provided in Table S7. Internal standards were added only prior to injection to avoid interference with bioassay analysis. Testosterone ${ }^{13} \mathrm{C}_{3}$ and androstenedione ${ }^{13} \mathrm{C}_{3}$ were added prior to $\mathrm{LC}$ analysis, while 6 deuterated analytes were added prior to GC/MS analysis (Table S6). In addition, a range of targeted chemicals were spiked into drinking water and treated wastewater and recovery by SPE was evaluated using LC-ESI-MS/MS. Further details can be found in Section S1, with good recovery 
(75-125\%) for the majority of spiked chemicals (Figure S1). Targeted chemical analysis was complemented with suspect screening using liquid chromatography - high resolution mass spectrometry (LC-HRMS) for 983 compounds with fragmentation data in the instrument's database. Diuron D6 was added as an internal standard prior to evaporation and injection in LC-HRMS. Further information about the LC-HRMS method can be found in Table S8.

\subsection{Bioanalysis}

Ten bioassays covering 14 different endpoints were applied in the current study. A summary of the studied assays is provided in Table 1. With the exception of RXR-CALUX, detailed descriptions of all bioassays have been previously published, with the references provided in Table 1 . RXRCALUX is a recently developed assay, but follows the same protocol of the other CALUX assays, with further information about the CALUX protocol found in Piersma et al. (2013). To ensure reliable results, all extracts were serially diluted and run in duplicate on each plate and tested on at least two separate occasions. Further, each plate included a full reference compound concentrationeffect curve, solvent controls and media controls for quality control.

\subsection{Data evaluation}

The concentration causing $50 \%$ effect $\left(\mathrm{EC}_{50}\right)$ or $50 \%$ inhibition $\left(\mathrm{IC}_{50}\right)$ for the assay reference compounds were derived from log-sigmoidal concentration-effect curves using Equation 1. The minimum effect (min) was set to $0 \%$ and the maximum effect (max) was set to $100 \%$, while the slope was an adjustable parameter. The concentration-effect curves for the assay reference compounds are provided in Figure S2.

$$
\% \text { effect }=\frac{\max -\min }{1+10^{\text {slope }\left(\log \mathrm{EC}_{50}-\log \text { concentration }\right)}}
$$


Table 1: Summary of the applied bioassays with the concentration causing 50\% effect $\left(\mathrm{EC}_{50}\right)$ or 50\% inhibition $\left(\mathrm{IC}_{50}\right)$ and the assay limit of quantification (LOQbio $)(\mathrm{M})$.

\begin{tabular}{|c|c|c|c|c|c|c|}
\hline Mode of action & Bioassay name & Mode & Reference compound & Reference & $\begin{array}{l}\text { Reference compound } \\
\qquad \mathrm{EC}_{50} \text { (agonist) or } \\
\text { IC }_{50} \text { (antagonist) (M) }\end{array}$ & $\begin{array}{c}\text { Limit of } \\
\text { quantification } \\
\left(\mathrm{LOQ}_{\text {bio }}\right)(\mathrm{M})^{*}\end{array}$ \\
\hline $\begin{array}{l}\text { Estrogen Receptor } \\
\qquad(\mathrm{ER} \alpha)\end{array}$ & ER-GeneBLAzer & $\begin{array}{c}\text { Agonist } \\
\text { Antagonist }\end{array}$ & $\begin{array}{l}\text { 17ß-Estradiol (E2) } \\
\text { 4-Hydroxytamoxifen }\end{array}$ & $\begin{array}{l}\text { König et al. (2017) } \\
\text { König et al. (2017) }\end{array}$ & $\begin{array}{l}3.4 \times 10^{-11} \\
4.7 \times 10^{-8}\end{array}$ & $\begin{array}{l}2.5 \times 10^{-12} \\
1.8 \times 10^{-9}\end{array}$ \\
\hline $\begin{array}{l}\text { Androgen Receptor } \\
\text { (AR) }\end{array}$ & AR-GeneBLAzer & $\begin{array}{c}\text { Agonist } \\
\text { Antagonist }\end{array}$ & $\begin{array}{c}{\mathrm{R} 1881^{\mathrm{a}}}^{\text {Cyproterone acetate }^{\mathrm{b}}}\end{array}$ & $\begin{array}{l}\text { König et al. (2017) } \\
\text { König et al. (2017) }\end{array}$ & $\begin{array}{l}6.5 \times 10^{-10} \\
6.0 \times 10^{-8}\end{array}$ & $\begin{array}{l}1.3 \times 10^{-10} \\
1.6 \times 10^{-8}\end{array}$ \\
\hline \multirow{2}{*}{$\begin{array}{l}\text { Glucocorticoid } \\
\text { Receptor (GR) }\end{array}$} & GR-GeneBLAzer & $\begin{array}{c}\text { Agonist } \\
\text { Antagonist }\end{array}$ & $\begin{array}{c}\text { Dexamethasone } \\
\text { Mifepristone (RU486) }\end{array}$ & $\begin{array}{l}\text { König et al. (2017) } \\
\text { König et al. (2017) }\end{array}$ & $\begin{array}{l}5.9 \times 10^{-10} \\
3.7 \times 10^{-10}\end{array}$ & $\begin{array}{l}2.6 \times 10^{-10} \\
1.9 \times 10^{-10}\end{array}$ \\
\hline & GR-CALUX & Agonist & Dexamethasone & Van der Linden et al. (2008) & $4.4 \times 10^{-9}$ & $1.3 \times 10^{-9}$ \\
\hline \multirow{2}{*}{$\begin{array}{l}\text { Progesterone } \\
\text { Receptor (PR) }\end{array}$} & PR-GeneBLAzer & $\begin{array}{c}\text { Agonist } \\
\text { Antagonist }\end{array}$ & $\begin{array}{c}\text { Levonorgestrel } \\
\text { Mifepristone (RU486) }\end{array}$ & $\begin{array}{l}\text { König et al. (2017) } \\
\text { König et al. (2017) }\end{array}$ & $\begin{array}{l}1.1 \times 10^{-10} \\
1.5 \times 10^{-10}\end{array}$ & $\begin{array}{l}2.5 \times 10^{-12} \\
7.6 \times 10^{-12}\end{array}$ \\
\hline & PR-CALUX & Agonist & Org2058 & Van der Linden et al. (2008) & $3.8 \times 10^{-10}$ & $7.3 \times 10^{-11}$ \\
\hline $\begin{array}{c}\text { Thyroid Receptor } \\
\text { (TR) }\end{array}$ & GH3.TRE-Luc & Agonist & Triiodothyronine (T3) & Freitas et al. (2011) & $1.6 \times 10^{-10}$ & $3.8 \times 10^{-11}$ \\
\hline $\begin{array}{c}\text { Retinoid X } \\
\text { Receptor (RXR) }\end{array}$ & RXR-CALUX & Agonist & Trans retinoic acid (tRA) & N/A & $2.4 \times 10^{-7}$ & $2.8 \times 10^{-8}$ \\
\hline $\begin{array}{c}\text { Retinoid Acid } \\
\text { Receptor (RAR } \alpha)\end{array}$ & HELN RAR $\alpha-R X R$ & $\begin{array}{c}\text { Agonist } \\
\text { RAR/RXR }\end{array}$ & TTNPB & Balaguer et al. (2001) & $4.8 \times 10^{-9}$ & $1.6 \times 10^{-9}$ \\
\hline
\end{tabular}




\begin{tabular}{cccccc} 
and Retinoid X & Antagonist & BMS493 & Balaguer et al. (2001) & $2.7 \times 10^{-9}$ \\
Receptor (RXR) & RAR/RXR & & & \\
\hline Mineralocorticoid & HG5LN MR & Agonist & Aldosterone & Bellet et al. (2012) & $9.8 \times 10^{-10}$ \\
Receptor (MR) & & Antagonist & Spironolactone & Bellet et al. (2012) & $4.0 \times 10^{-9}$
\end{tabular}

${ }^{a} 5 \alpha$-dihydrotestosterone (DHT) with an $\mathrm{EC}_{50}$ of $2.20 \times 10^{-9} \mathrm{M}$ (Leusch et al., 2017) used for BEQ calculations; ${ }^{b}$ flutamide with an $\mathrm{EC}_{50}$ of $2.20 \times 10^{-6} \mathrm{M}$ (Leusch et al., 2017 ) used for BEQ calculations; ${ }^{c}$ levonorgestrel with an $\mathrm{EC}_{50}$ of $1.4 \times 10^{-10} \mathrm{M}$ (Leusch et al., 2017) used for BEQ calculations

* $\mathrm{LOQ}_{\mathrm{bio}}$ set as the concentration causing $10 \%$ effect $\left(\mathrm{EC}_{10}\right)$ in agonist mode or the concentration causing $20 \%$ inhibition $\left(\mathrm{IC}_{20}\right)$ in antagonist mode, with the exception of ER-

GeneBLAzer (agonist mode) and PR-CALUX where the $\mathrm{LOQ}_{\text {bio }}$ was set as the concentration causing $5 \%$ effect $\left(\mathrm{EC}_{05}\right)$

TTNPB: [E]-4-[2-(5, 6, 7, 8-tetrahydro-5, 5, 8, 8-tetramethyl-2-naphthalenyl)propen-1-yl]benzoic acid 
The LOQ for each bioassay ( $\mathrm{LOQ}_{\text {bio }}$ ) was calculated as the baseline (i.e. the raw bioassay response with negative control samples) plus $10 \times$ the standard deviation of the baseline. This was close to $10 \%$ for most agonist assays; therefore, the $\mathrm{LOQ}_{\mathrm{bio}}$ was set to the concentration causing $10 \%$ effect $\left(\mathrm{EC}_{10}\right)$. The baseline was less variable in the ER-GeneBLAzer and PR-CALUX assays, so the $\mathrm{LOQ}_{\text {bio }}$ was set to the concentration causing $5 \%$ effect $\left(\mathrm{EC}_{05}\right)$. The $\mathrm{LOQ}_{\text {bio }}$ in antagonist mode was set as the concentration causing $20 \%$ inhibition $\left(\mathrm{IC}_{20}\right)$ due to the greater variability in the response of the negative control. The $\mathrm{LOQ}_{\text {bio }}$ for each assay is provided in Table 1.

With exception of some extracts in the AR-GeneBLAzer assay, the responses in most

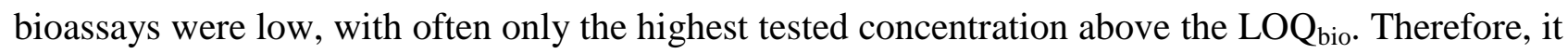
was not possible to derive an EC value from a linear or log-sigmoidal concentration-effect curve. Instead, the biological activity in the sample, expressed as either $\mathrm{EC}_{10}$ or $\mathrm{IC}_{20}$ in units of relative enrichment factor (REF), was calculated from the positive response using Equation 2, where $\mathrm{EC}_{\mathrm{x}}$ or $\mathrm{IC}_{\mathrm{x}}$ is the concentration in units of REF at $\mathrm{x} \%$ level and $\mathrm{x} \%$ is the percent effect of the sample. REF was calculated based on the sample enrichment factor by SPE and the dilution factor in the assay (Escher and Leusch, 2012).

$$
\mathrm{EC}_{10}=\mathrm{EC}_{\mathrm{x}} \cdot \frac{10 \%}{\mathrm{x} \%} \quad \text { or } \quad \mathrm{IC}_{20}=\mathrm{IC}_{\mathrm{x}} \cdot \frac{20 \%}{\mathrm{x} \%}
$$

Sample $\mathrm{EC}_{10}$ or $\mathrm{IC}_{20}$ values in units of $\mathrm{REF}$ were converted to bioanalytical equivalent concentrations from bioassays $\left(\mathrm{BEQ}_{\mathrm{bio}}\right)$ using Equation 3 in order to translate the effect of a sample to the concentration of a reference compound that would elicit the same response. For comparison with previous studies on endocrine activity in environmental waters, the equivalent concentrations for AR-GeneBLAzer were reported as $5 \alpha$-dihydrotestosterone equivalents (DHTEQ) in agonist mode and flutamide equivalents (FluEQ) in antagonist mode using EC values from Leusch et al. 
(2017). Further, levonorgestrel equivalents (LevoEQ) were reported for PR-CALUX in agonist mode using the EC value from Leusch et al. (2017). These values are provided in the footnote to Table 1. BEQ ${ }_{\text {bio }}$ was expressed in units of $\mathrm{ng} / \mathrm{L}$.

$$
\mathrm{BEQ}_{\mathrm{bio}}=\frac{\mathrm{EC}_{10}(\text { reference compound })}{\left.\mathrm{EC}_{10} \text { (sample }\right)} \quad \text { or } \quad \frac{\left.\mathrm{IC}_{20} \text { (reference compound }\right)}{\mathrm{IC}_{20} \text { (sample) }}
$$

\section{Results and Discussion}

\subsection{Chemical Analysis}

Of the 58 chemicals monitored by targeted chemical analysis, only 23 were detected above the $\mathrm{LOQ}_{\text {chem }}$ in the water extracts (Table 2). $\mathrm{LOQ}_{\text {chem }}$ was in the high nanogram per litre concentration range for some chemicals (Table S7) and this could be attributed to the limited sample enrichment and small sample volumes $(100 \mu \mathrm{L})$. However, for the majority of detected chemicals, the concentration detected was much higher than the $\mathrm{LOQ}_{\text {chem, }}$ with the detected concentration on average 60 times higher than the $\mathrm{LOQ}_{\mathrm{chem}}$. Further, 149 compounds were qualitatively identified with medium to high confidence from a database of 983 compounds with fragmentation data during suspect screening (Table S9). As the water samples are grab samples and each matrix was collected for one location per country, the results represent a snapshot and it is difficult to make any countryspecific generalisations; however, some trends were apparent. For example, pesticides diazinon and chlorpyrifos, which are banned in Europe, were only detected in Australian water extracts. A more representative longer-term sampling campaign is required to better understand micropollutant contamination patterns in different geographic regions.

An overview of the detected chemicals by chemical class is shown in Figure 1. Treated wastewater had the highest sum chemical concentration, with pharmaceuticals the dominant detected chemical class, while drinking water and control ultrapure water had the lowest sum chemical concentrations, with mostly industrial compounds detected (Figure 1, Table 2). The 
Table 2: Summary of detected chemicals in units of $\mathrm{ng} / \mathrm{L}$, along with the limit of quantification (LOQ $\mathrm{Q}_{\mathrm{chem}}$ ). Identification of the analytes was confirmed by multiple reaction monitoring (MRM) using the two most representative transitions from the precursor ion to the different product ions. The chemicals were grouped into classes including hormones, industrial compounds, personal care products, pesticides and pharmaceuticals $(\mathrm{WW}=$ treated wastewater; $\mathrm{DW}=$ drinking; $\mathrm{SW}=$ surface; $\mathrm{CW}=\mathrm{control}$ water, i.e. ultrapure water) Values above LOQ are bolded and highlighted in grey.

\begin{tabular}{|c|c|c|c|c|c|c|c|c|c|c|c|c|c|c|c|c|c|c|c|c|c|c|c|c|}
\hline \multirow{3}{*}{$\begin{array}{c}\text { Type } \\
I D\end{array}$} & \multicolumn{4}{|c|}{ Germany } & \multicolumn{4}{|c|}{ Australia } & \multicolumn{4}{|c|}{ France } & \multicolumn{4}{|c|}{ South Africa } & \multicolumn{4}{|c|}{ The Netherlands } & \multicolumn{4}{|c|}{ Spain } \\
\hline & $W W$ & $D W$ & $S W$ & $C W$ & $W W$ & $D W$ & $S W$ & $C W$ & $W W$ & $D W$ & $S W$ & $C W$ & $W W$ & $D W$ & $S W$ & $C W$ & $W W$ & $D W$ & $S W$ & $C W$ & $W W$ & $D W$ & $S W$ & $C W$ \\
\hline & 1 & 2 & 3 & 4 & 5 & 6 & 7 & 8 & 9 & 10 & 11 & 12 & 13 & 14 & 15 & 16 & 17 & 18 & 19 & 20 & 21 & 22 & 23 & 23 \\
\hline \multicolumn{25}{|c|}{ Hormones } \\
\hline Androstenedione & $<15$ & $<0.8$ & $<3$ & $<3$ & 36 & $<0.8$ & $<3$ & $<3$ & $<15$ & $<0.8$ & $<3$ & $<3$ & $<15$ & $<0.8$ & $<3$ & $<3$ & $<15$ & $<0.8$ & $<3$ & $<3$ & $<15$ & $<0.8$ & $<3$ & $<3$ \\
\hline Cortisone & $<6$ & $<0.3$ & $<1.2$ & $<1.2$ & $<6$ & $<0.3$ & $<1.2$ & $<1.2$ & $<6$ & $<0.3$ & $<1.2$ & $<1.2$ & $<6$ & $<0.3$ & $<1.2$ & $<1.2$ & $<6$ & $<0.3$ & $<1.2$ & $<1.2$ & $<6$ & $<0.3$ & 5.4 & $<1.2$ \\
\hline \multicolumn{25}{|c|}{ Industrial compounds } \\
\hline $\begin{array}{l}2,4,6- \\
\text { Trichlorophenol }\end{array}$ & $<100$ & $<5$ & $<20$ & $<20$ & $<100$ & 30 & $<20$ & $<20$ & $<100$ & $<5$ & $<20$ & $<20$ & $<100$ & $<5$ & $<20$ & $<20$ & $<100$ & $<5$ & $<20$ & $<20$ & $<100$ & $<5$ & $<20$ & $<20$ \\
\hline 4-Nonylphenol & $<400$ & $<20$ & $<80$ & $<80$ & $<400$ & $<20$ & 240 & $<80$ & $<400$ & 34 & $<80$ & 100 & $<400$ & $<20$ & $<80$ & $<80$ & $<400$ & $<20$ & $<80$ & $<80$ & $<400$ & 36 & $<80$ & $<80$ \\
\hline 4-t-Butylphenol & $<100$ & $<5$ & $<20$ & $<20$ & $<100$ & $<5$ & $<20$ & $<20$ & $<100$ & $<5$ & $<20$ & $<20$ & $<100$ & $<5$ & $<20$ & $<20$ & 300 & 490 & $<20$ & $<20$ & $<100$ & $<5$ & $<20$ & $<20$ \\
\hline 4-t-Octylphenol & $<10$ & $<0.5$ & $<2$ & $<2$ & $<10$ & $<0.5$ & $<2$ & $<2$ & $<10$ & $<0.5$ & 6 & $<2$ & $<10$ & $<0.5$ & $<2$ & $<2$ & $<10$ & $<0.5$ & $<2$ & $<2$ & $<10$ & $<0.5$ & $<2$ & $<2$ \\
\hline Bisphenol A & 540 & $<0.3$ & 13 & $<1$ & 130 & $<0.3$ & 100 & 19 & 22 & $<0.3$ & 28 & 160 & 200 & $<0.3$ & 23 & $<1$ & $<5$ & $<0.3$ & $<1$ & $<1$ & $<5$ & $<0.3$ & 5 & $<1$ \\
\hline Dibutylphthalate & $<100$ & 50 & 195 & $<20$ & $<100$ & 20 & $<20$ & $<20$ & $<100$ & 170 & 250 & $<20$ & $<100$ & 35 & 200 & $<20$ & $<100$ & $<5$ & $<20$ & $<20$ & $<100$ & 65 & $<20$ & 100 \\
\hline \multicolumn{25}{|c|}{ Personal care products } \\
\hline Triclocarban & $<5$ & $<0.3$ & $<1$ & $<1$ & $<5$ & $<0.3$ & $<1$ & $<1$ & $<5$ & $<0.3$ & $<1$ & $<1$ & $<5$ & $<0.3$ & $<1$ & $<1$ & 100 & $<0.3$ & $<1$ & $<1$ & 32 & $<0.3$ & 8 & $<1$ \\
\hline Triclosan & 104 & $<0.3$ & 4 & $<1$ & 500 & $<0.3$ & 100 & $<1$ & 140 & 0.4 & 3 & $<1$ & 210 & $<0.3$ & $<1$ & $<1$ & 340 & $<0.3$ & $<1$ & $<1$ & $<5$ & 1.3 & 4 & $<1$ \\
\hline \multicolumn{25}{|c|}{ Pesticides } \\
\hline Atrazine & $<2$ & $<0.1$ & 12 & $<0.4$ & $<2$ & $<0.1$ & $<0.4$ & $<0.4$ & 4 & 4 & 11 & $<0.4$ & $<2$ & $<0.1$ & $<0.4$ & $<0.4$ & $<0.1$ & $<0.4$ & $<0.4$ & 1 & 460 & 37 & 110 & $<0.4$ \\
\hline Carbendazim & 220 & $<0.3$ & 120 & $<1$ & 220 & $<0.3$ & 6 & $<1$ & $<5$ & $<1$ & 3 & $<1$ & 70 & $<0.3$ & $<1$ & $<1$ & 220 & $<0.3$ & 15 & $<1$ & 150 & $<0.3$ & $<1$ & $<1$ \\
\hline Chlorpyrifos & $<5$ & $<0.3$ & $<1$ & $<1$ & 10 & $<0.4$ & 3 & $<1$ & $<5$ & $<0.3$ & $<1$ & $<1$ & $<5$ & $<0.3$ & $<1$ & $<1$ & $<5$ & $<0.3$ & $<1$ & $<1$ & $<5$ & $<0.3$ & $<1$ & $<1$ \\
\hline Diazinon & $<10$ & $<0.5$ & $<2$ & $<2$ & 22 & $<0.5$ & $<2$ & $<2$ & $<10$ & $<0.5$ & $<2$ & $<2$ & $<10$ & $<0.5$ & $<2$ & $<2$ & $<10$ & $<0.5$ & $<2$ & $<2$ & $<10$ & $<0.5$ & $<2$ & $<2$ \\
\hline Diuron & $<5$ & $<0.3$ & 16 & $<1$ & 340 & $<0.3$ & 20 & $<1$ & 200 & $<0.3$ & 5 & $<1$ & 70 & $<0.3$ & 2 & $<1$ & 460 & $<0.3$ & 44 & $<1$ & 62 & 3.5 & 14 & $<1$ \\
\hline Linuron & $<5$ & $<0.3$ & $<1$ & $<1$ & 7 & $<0.3$ & $<1$ & $<1$ & $<5$ & $<0.3$ & $<1$ & $<1$ & 9 & $<0.3$ & 18 & $<1$ & $<5$ & $<0.3$ & $<1$ & $<1$ & $<5$ & $<0.3$ & $<1$ & $<1$ \\
\hline Simazine & $<2$ & $<0.1$ & 9 & $<0.4$ & 10 & $<0.1$ & $<0.4$ & $<0.4$ & 7 & $<0.1$ & 12 & $<0.4$ & $<2$ & $<0.1$ & $<0.4$ & $<0.4$ & $<2$ & 3 & 64 & 1 & 260 & 14 & 56 & $<0.4$ \\
\hline \multicolumn{25}{|c|}{ Pharmaceuticals } \\
\hline Amiodarone & $<20$ & $<1$ & $<4$ & $<4$ & $<20$ & $<1$ & $<4$ & $<4$ & $<20$ & $<1$ & $<4$ & $<4$ & $<20$ & $<1$ & $<4$ & $<4$ & $<20$ & $<1$ & $<4$ & $<4$ & $<20$ & $<1$ & 10 & $<1$ \\
\hline Atenolol & $<200$ & $<10$ & $<40$ & $<40$ & 1300 & $<10$ & $<40$ & $<40$ & 720 & $<10$ & $<40$ & $<40$ & 940 & $<10$ & $<40$ & $<40$ & 1000 & $<10$ & $<40$ & $<40$ & $<200$ & $<10$ & $<40$ & $<40$ \\
\hline Carbamazepine & 2200 & $<0.3$ & 120 & $<1$ & 360 & $<0.3$ & 30 & $<1$ & 2000 & $<0.3$ & 60 & $<1$ & 860 & $<0.3$ & 3 & $<1$ & 740 & $<0.3$ & $<1$ & $<1$ & 1100 & 59 & 320 & $<1$ \\
\hline Diazepam & $<10$ & $<0.5$ & $<2$ & $<2$ & 24 & $<0.5$ & $<2$ & $<2$ & $<10$ & $<0.5$ & $<2$ & $<2$ & $<10$ & $<0.5$ & $<2$ & $<2$ & 12 & $<0.5$ & $<2$ & $<2$ & $<10$ & $<0.5$ & $<2$ & $<2$ \\
\hline Diclofenac & 2400 & $<0.3$ & 52 & $<1$ & 1200 & $<0.3$ & 56 & $<1$ & 2000 & $<0.3$ & 10 & 3 & 300 & $<0.3$ & $<1$ & $<1$ & 820 & $<0.3$ & $<1$ & $<1$ & $<5$ & $<0.3$ & $<1$ & $<1$ \\
\hline Mefenamic acid & $<2$ & $<0.1$ & 6 & $<0.4$ & 34 & $<0.1$ & $<0.4$ & $<0.4$ & 100 & $<0.1$ & $<0.4$ & $<0.4$ & 5 & $<0.1$ & $<0.4$ & $<0.4$ & $<2$ & $<0.1$ & $<0.4$ & $<0.4$ & $<2$ & $<0.1$ & 4 & $<0.4$ \\
\hline
\end{tabular}

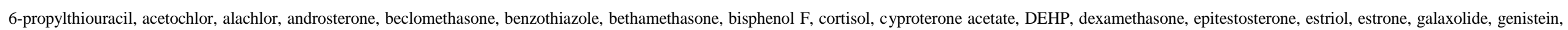
L-thyroxine, levonorgestrel, mestranol, norethisterone, pentachlorophenol, progesterone, testosterone, tetrabromobisphenol A, TETRAC, tonalide, TRIAC, trifluralin. LOQ ${ }_{\text {chem }}$ for these chemicals is provided in Table S7. 
Figure 1: Sum chemical concentration detected in each country (nM) by chemical class excluding hormones (left axis) for treated wastewater, surface water, drinking water and ultrapure water, with sum hormone concentration (right axis) for treated wastewater and surface water. Note different y-axis scales in each figure. A list of chemicals included in the different classes is provided in Table 2.
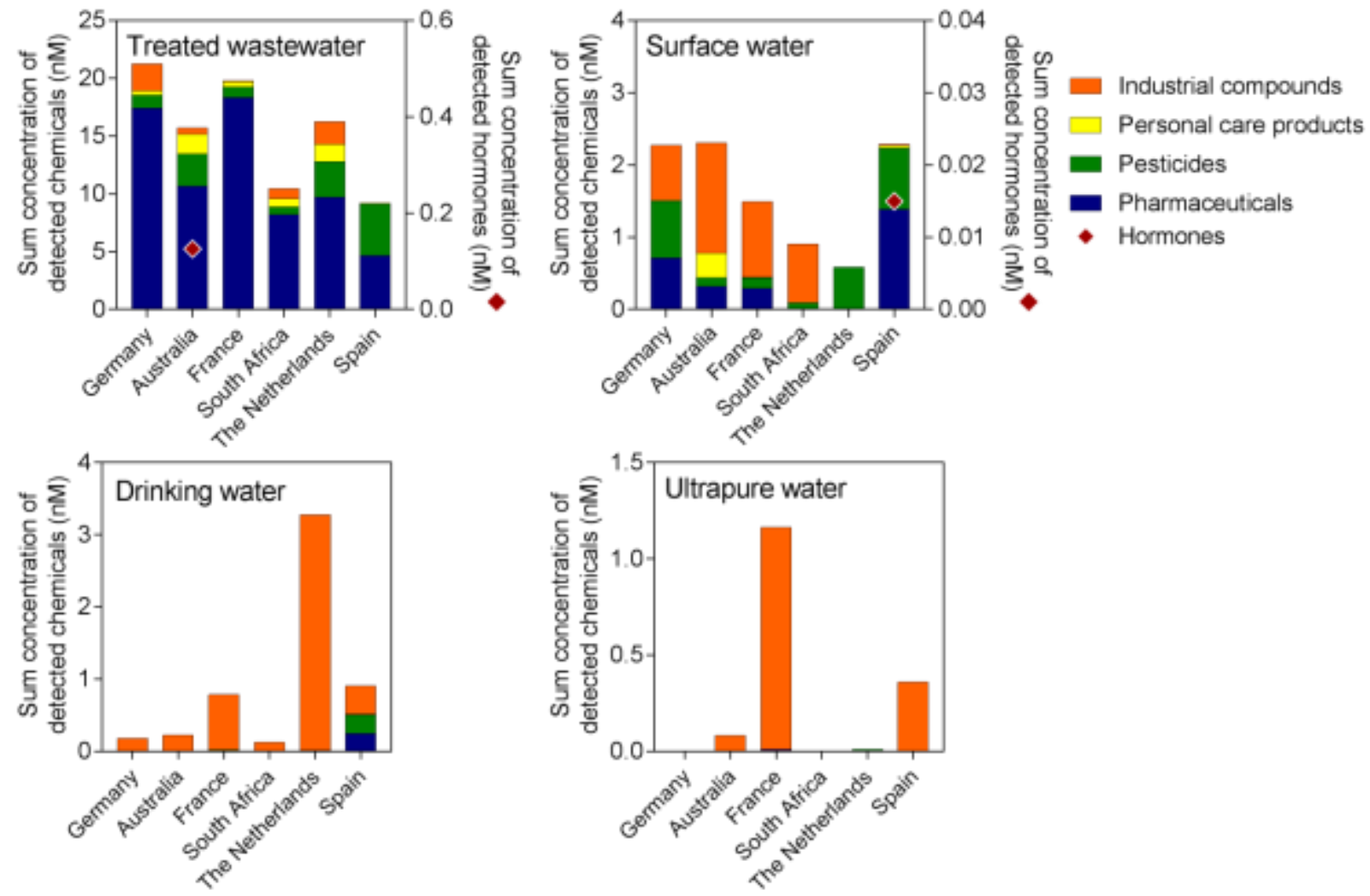

pharmaceuticals diclofenac $(\mathrm{n}=5$, median concentration $1200 \mathrm{ng} / \mathrm{L})$, carbamazepine $(\mathrm{n}=6$, median concentration $980 \mathrm{ng} / \mathrm{L}$ ) and atenolol ( $\mathrm{n}=4$, median concentration $970 \mathrm{ng} / \mathrm{L}$ ) were detected up to the microgram per litre concentration range in treated wastewater, while personal care product triclosan ( $\mathrm{n}=5$, median concentration $210 \mathrm{ng} / \mathrm{L})$, industrial compound bisphenol A $(\mathrm{n}=4$, median concentration $165 \mathrm{ng} / \mathrm{L})$ and herbicide diuron ( $\mathrm{n}=5$, median concentration $200 \mathrm{ng} / \mathrm{L})$ were found in the high nanogram per litre concentration range. These chemicals were also detected in surface water, with the exception of atenolol, though the median concentrations were 7 to 50 times lower than in treated wastewater. Hormones were only detected in treated wastewater and surface water. While our dataset is limited to one type of grab sample from each country, the profile of chemicals 
in surface waters differed with the studied countries, suggesting varying sources of contamination in the collected samples (Figure 1). For example, pharmaceuticals dominated the surface water profile from Spain, with the sampled river known to be impacted by urban and industrial wastewater (Table S1), while only pesticides (carbendazim, diuron and simazine) were detected in surface water from the Netherlands, which was collected from a lake in a rural area.

Nine compounds were detected in drinking water, with concentrations typically in the low nanogram per litre range. The plasticiser dibutyl phthalate was detected in 5 out of 6 of the drinking water extracts, with atrazine, simazine, 4-nonylphenol and triclosan each detected in 2 out of 6 drinking water samples. 4- $t$-Butylphenol was detected at a concentration of $460 \mathrm{ng} / \mathrm{L}$ in the drinking water extract from the Netherlands, but was not detected in drinking water extracts for any other country. In addition, carbamazepine and diuron were both detected at low concentrations in drinking water from Spain. Further, industrial compounds 4-nonylphenol, bisphenol A and dibutyl phthalate were found in ultrapure water. While dibutyl phthalate was found in 5 of 6 drinking water samples, it should not be considered an artefact, as it was only detected in one ultrapure water sample. However, the widespread presence of plasticisers, particularly in the laboratory, means that they are often detected at low concentrations in ultrapure waters (Devier et al., 2013).

\subsection{Bioanalysis}

A summary of all bioassay results, expressed as $\mathrm{BEQ}_{\mathrm{bio}}$, is provided in Table 3. Despite the wide coverage of endpoints applied to four different water matrices from 6 countries, the observed effects in the extracts were generally low. None of the samples had a response in agonist mode for the GRCALUX, PR-CALUX, GH3.TRE-Luc, RXR-CALUX, HELN-RARa-RXR or HG5LN-MR assays or in antagonist mode for the ER-GeneBLAzer, AR-GeneBLAzer, GR-GeneBLAzer, PRGeneBLAzer or HELN-RARa-RXR assays. The surface water from Spain was the most active sample, with an estradiol equivalent concentration (EEQ) of $0.31 \mathrm{ng} / \mathrm{L}$ in ER-GeneBLAzer, a dexamethasone equivalent concentration (DexaEQ) of $96 \mathrm{ng} / \mathrm{L}$ in GR-GeneBLAzer, a LevoEQ of 


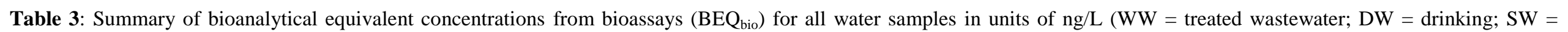
surface; $\mathrm{CW}=$ control water, i.e. ultrapure water).

\begin{tabular}{|c|c|c|c|c|c|c|c|c|c|c|c|c|c|c|c|c|c|c|}
\hline \multirow[b]{2}{*}{ ID } & \multirow[b]{2}{*}{ Type } & \multirow{3}{*}{ Country } & \multicolumn{2}{|c|}{ ER-GeneBLAzer } & \multicolumn{2}{|c|}{ AR-GeneBLAzer } & \multicolumn{2}{|c|}{ GR-GeneBLAzer } & $\begin{array}{c}\text { GR- } \\
\text { CALUX }\end{array}$ & \multicolumn{2}{|c|}{ PR-GeneBLAzer } & \multirow{2}{*}{$\begin{array}{c}\text { PR- } \\
\text { CALUX } \\
\text { Levo }\end{array}$} & \multirow{2}{*}{$\begin{array}{c}\text { GH3.TR } \\
\text { E-Luc } \\
\text { T3EQ }\end{array}$} & \multirow{2}{*}{$\begin{array}{c}\text { RXR- } \\
\text { CALUX } \\
\text { tRAEQ }\end{array}$} & \multicolumn{2}{|c|}{ HELN-RARa-RXR } & \multicolumn{2}{|c|}{ HG5LN-MR } \\
\hline & & & EEQ & OHTMX & DHT & Flu & Dexa & Mif & Dexa & Levo & Mif & & & & TTNPB & BMS493 & AldoEQ & SpiroEQ \\
\hline & & & & EQ & EQ & EQ & EQ & EQ & EQ & EQ & EQ & EQ & & & EQ & EQ & & \\
\hline 1 & WW & Germany & $<0.6$ * & $<4200$ & $<4$ & $<15000$ & $<120$ & $<60$ & $<2500$ & $<2.5$ & $<2$ & $<33$ & $<25$ & $<2100$ & $<2000$ & $<1000$ & $<600$ & $<3100 *$ \\
\hline 5 & WW & Australia & $<0.6$ & $<4200$ & $<2$ & $<22000$ & $<120$ & $<60$ & $<2500$ & $<2.5$ & $<2$ & $<33$ & $<25$ & $<2100$ & $<2000$ & $<1000$ & $<600$ & $<3100$ \\
\hline 9 & WW & France & 0.78 & $<4200$ & $<2$ & $<15000$ & $<120$ & $<60$ & $<2500$ & $<2.5$ & $<2$ & $<33$ & $<25$ & $<2100$ & $<2000$ & $<1000$ & $<600$ & $<3100 *$ \\
\hline 13 & WW & South Africa & $<0.6$ & $<4200$ & $<4$ & $<15000$ & $<120$ & $<60$ & $<2500$ & $<2.5$ & $<2$ & $<33$ & $<25$ & $<2100$ & $<2000$ & $<1000$ & $<600$ & $<3100 *$ \\
\hline 17 & WW & Netherlands & $<0.6$ & $<4200$ & $<2$ & $<15000$ & $<120$ & $<60$ & $<2500$ & $<2.5$ & $<2$ & $<33$ & $<25$ & $<2100$ & $<2000$ & $<1000$ & $<600$ & $<3100$ \\
\hline 21 & WW & Spain & $<0.6$ & $<4200$ & $<2$ & $<15000$ & 130 & $<60$ & $<2500$ & $<2.5$ & $<2$ & $<33$ & $<25$ & $<2100$ & $<2000$ & $<1000$ & $<600$ & 3100 \\
\hline 3 & SW & Germany & $<0.1$ & $<830$ & $5(2 \dagger)$ & $<2900$ & $<23$ & $<12$ & $<500$ & $<0.5$ & $<0.4$ & $<7$ & $<20$ & $<400$ & $<400$ & $<200$ & $<120$ & $<620 *$ \\
\hline 7 & SW & Australia & $<0.1$ & $<830$ & $<1$ & $<4400$ & $<23$ & $<12$ & $<500$ & $<0.5$ & $<0.4$ & $<7$ & $<20$ & $<400$ & $<400$ & $<200$ & $<120$ & $<620$ \\
\hline 11 & SW & France & $<0.1$ & $<830$ & $<1$ & $<5800$ & $<23$ & $<12$ & $<500$ & $<0.5$ & $<0.4$ & $<7$ & $<20$ & $<400$ & $<400$ & $<200$ & $<120$ & 660 \\
\hline 15 & SW & South Africa & $<0.1$ & $<830$ & $<1$ & $<5800$ & $<23$ & $<12$ & $<500$ & $<0.5$ & $<0.4$ & $<7$ & $<20$ & $<400$ & $<400$ & $<200$ & $<120$ & $<620$ \\
\hline 19 & SW & Netherlands & $<0.1$ & $<830$ & $<1$ & $<4400$ & $<23$ & $<12$ & $<500$ & $<0.5$ & $<0.4$ & $<7$ & $<20$ & $<400$ & $<400$ & $<200$ & $<120$ & $<620$ \\
\hline 23 & SW & Spain & 0.31 & $<830$ & $<1$ & $<8900$ & 96 & $<12$ & $<500$ & 1.1 & $<0.4$ & $<2$ & $<20$ & $<400$ & $<400$ & $<200$ & $<120$ & 910 \\
\hline 2 & DW & Germany & $<0.03$ & $<210$ & $5(2 \dagger)$ & $<700$ & $<5.8$ & $<3$ & $<120$ & $<0.1$ & $<0.1$ & $<2$ & $<1.3$ & $<100$ & $<90$ & $<50$ & $<30$ & $<160$ \\
\hline 6 & DW & Australia & $<0.03$ & $<210$ & $<0.1$ & $<4400$ & $<5.8$ & $<3$ & $<120$ & $<0.1$ & $<0.1$ & $<2$ & $<1.3$ & $<100$ & $<90$ & $<50$ & $<30$ & $<160$ \\
\hline 10 & DW & France & $<0.03$ & $<210$ & $<0.1$ & $<700$ & $<5.8$ & $<3$ & $<120$ & $<0.1$ & $<0.1$ & $<2$ & $<1.3$ & $<100$ & $<90$ & $<50$ & $<30$ & $<160$ \\
\hline 14 & DW & South Africa & $<0.03$ & $<210$ & $<1$ & $<2900$ & $<5.8$ & $<3$ & $<120$ & $<0.1$ & $<0.1$ & $<2$ & $<1.3$ & $<100$ & $<90$ & $<50$ & $<30$ & $<160$ \\
\hline 18 & DW & Netherlands & $<0.03$ & $<210$ & $<0.1$ & $<700$ & $<5.8$ & $<3$ & $<120$ & $<0.1$ & $<0.1$ & $<2$ & $<1.3$ & $<100$ & $<90$ & $<50$ & $<30$ & $<160$ \\
\hline 22 & DW & Spain & $<0.03$ & $<210$ & $<0.4$ & $<2200$ & $<5.8$ & $<3$ & $<120$ & $<0.1$ & $<0.1$ & $<2$ & $<1.3$ & $<100$ & $<90$ & $<50$ & $<30$ & $<160$ \\
\hline
\end{tabular}




\begin{tabular}{|c|c|c|c|c|c|c|c|c|c|c|c|c|c|c|c|c|c|c|}
\hline 4 & CW & Germany & $<0.1$ & $<830$ & 3 & $<1800$ & $<23$ & $<12$ & $<500$ & $<0.5$ & $<0.4$ & $<7$ & $<5$ & $<400$ & $<400$ & $<200$ & $<120$ & $<620$ \\
\hline 8 & CW & Australia & $<0.1$ & $<830$ & $<0.3$ & $<1800$ & $<23$ & $<12$ & $<500$ & $<0.5$ & $<0.4$ & $<7$ & $<5$ & $<400$ & $<400$ & $<200$ & $<120$ & $<620$ \\
\hline 12 & CW & France & $<0.1$ & $<830$ & $<0.3$ & $<1800$ & $<23$ & $<12$ & $<500$ & $<0.5$ & $<0.4$ & $<7$ & $<5$ & $<400$ & $<400$ & $<200$ & $<120$ & $<620$ \\
\hline 16 & CW & South Africa & $<0.1$ & $<830$ & $<0.3$ & $<1800$ & $<23$ & $<12$ & $<500$ & $<0.5$ & $<0.4$ & $<7$ & $<5$ & $<400$ & $<400$ & $<200$ & $<120$ & $<620$ \\
\hline 20 & CW & Netherlands & $<0.1$ & $<830$ & $<0.3$ & $<1800$ & $<23$ & $<12$ & $<500$ & $<0.5$ & $<0.4$ & $<7$ & $<5$ & $<400$ & $<400$ & $<200$ & $<120$ & $<620$ \\
\hline 24 & $\mathrm{CW}$ & Spain & $<0.1$ & $<830$ & $<0.3$ & $<1800$ & $<23$ & $<12$ & $<500$ & $<0.5$ & $<0.4$ & $<7$ & $<5$ & $<400$ & $<400$ & $<200$ & $<120$ & $<620$ \\
\hline
\end{tabular}

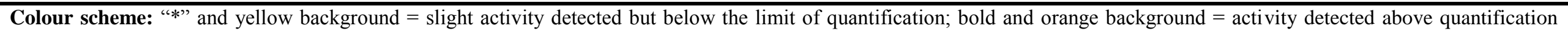

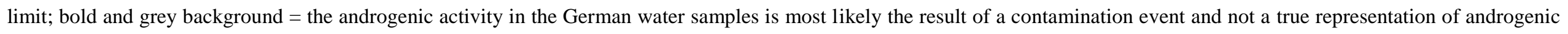
activity in those samples.

$\uparrow \mathrm{BEQ}_{\text {bio }}$ (blank-corrected sample) provided in brackets.

$<$ indicates the sample did not have an effect in the assay up to the maximum tested concentration.

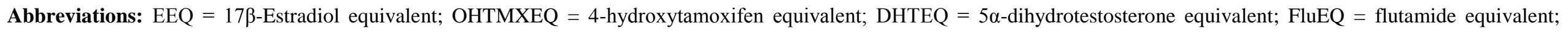

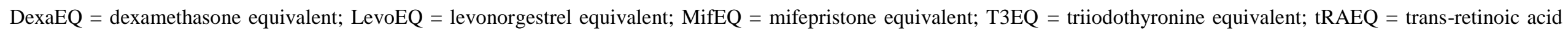
equivalent; TTNPBEQ = TTNPB equivalent; BMS493EQ = BMS493 equivalent; AldoEQ = aldosterone equivalent; SpiroEQ = spironolactone equivalent. 
$1.1 \mathrm{ng} / \mathrm{L}$ in PR-GeneBLAzer and a spironolactone equivalent concentration (SpiroEQ) of $910 \mathrm{ng} / \mathrm{L}$ in HG5LN-MR (antagonist mode). This water extract also had the highest sum chemical concentration of all surface water samples, with pharmaceuticals as the main chemical class detected. Treated wastewater from Spain also had a response in the GR-GeneBLAzer (130 ng/L DexEQ) and HG5LN-MR (3100 ng/L SpiroEQ) assays. Both GeneBLAzer and CALUX assays were applied to assess activation of GR and PR, with responses observed in the GeneBLAzer assays, but not in the equivalent CALUX assays. As can be seen in Table 1, the LOQ for the GeneBLAzer assays, which can be attributed to a combination of sensitivity and ability to tolerate higher solvent concentrations (Leusch et al., 2017).

Treated wastewater from France also had an effect in the ER-GeneBLAzer assay $(0.78 \mathrm{ng} / \mathrm{L}$ EEQ), while surface water from France had an effect in the HG5LN-MR assay (660 ng/L SpiroEQ). Three samples from Germany, surface water, drinking water and ultrapure water, induced a response in the AR-GeneBLAzer assay in agonist mode, with no effects observed in the treated wastewater effluent from Germany or any extracts from other countries. This result is unusual and is likely due to sample contamination given that the activity was comparable in all three samples including the ultrapure water (3 to $5 \mathrm{ng} / \mathrm{L}$ DHTEQ), which is unlikely as they represent different matrices. Further, no known androgenic chemicals were detected in drinking water, while no chemicals were present about the $\mathrm{LOQ}_{\text {chem }}$ in the German ultrapure water. Therefore, the activity in these samples was not considered to be representative of typical water samples. The BEQ bio of a blank sample can be subtracted from the $\mathrm{BEQ}_{\text {bio }}$ of a sample to find the blank-corrected sample $\mathrm{BEQ}_{\text {bio }}$ (Neale et al., 2018). Applying this approach in the current study, a blank-corrected DHTEQ of $2 \mathrm{ng} / \mathrm{L}$ for both the surface water and drinking water extracts could be calculated.

While the results of the current study only provide a snapshot, they were generally within an order of magnitude of previously detected hormonal activity (Table 4). Higher estrogenic activity in treated wastewater and surface water, as well as higher anti-androgenic and anti-progestagenic activity in surface water, was reported in the literature (as recently reviewed by Leusch et al. 
Table 4: Bioactivity in water samples determined in the current study and compared with values previously reported in the literature (n/a: not available). Literature data were reviewed in Leusch et al. (2017).

\begin{tabular}{|c|c|c|c|c|c|c|c|}
\hline \multirow[b]{2}{*}{ Activity } & \multirow[b]{2}{*}{ Units } & \multicolumn{2}{|c|}{ Treated wastewater } & \multicolumn{2}{|c|}{ Surface water } & \multicolumn{2}{|c|}{ Drinking water } \\
\hline & & Current study & Literature $^{a}$ & Current study & Literature $^{a}$ & Current study & Literature $^{a}$ \\
\hline ER & EEQ (ng/L) & $<0.6-0.78$ & $<0.03-68$ & $<0.1-0.31$ & $<0.01-23$ & $<0.03$ & $<0.001-0.08$ \\
\hline Anti-ER & OHTMXEQ (ng/L) & $<4200$ & $<500$ & $<830$ & $<260$ & $<210$ & $1.3-11.6$ \\
\hline AR & DHTEQ (ng/L) & $<4$ & $<0.1-20$ & $<1$ & $<0.1-12$ & $<1$ & $<0.01-6.3$ \\
\hline Anti-AR & FluEQ (ng/L) & $<22000$ & Up to 36000 & $<8900$ & Up to 260000 & $<4400$ & $<41-1000$ \\
\hline GR & DexaEQ (ng/L) & $<120-130$ & $<3-188$ & $<23-96$ & $<0.4-34$ & $<5.8$ & $<0.5-13$ \\
\hline Anti-GR & MifEQ (ng/L) & $<60$ & $<8$ & $<12$ & $<15$ & $<3$ & $<15$ \\
\hline PR & LevoEQ (ng/L) & $<2.5$ & $<0.01-7.1$ & $<0.4-1.1$ & $<0.1-8.7$ & $<0.1$ & $<0.01$ \\
\hline Anti-PR & MifEQ (ng/L) & $<2$ & $<7$ & $<0.4$ & $<8-32000$ & $<0.1$ & $<13$ \\
\hline TR & T3EQ (ng/L) & $<25$ & $<1.5$ & $<20$ & $<1.5$ & $<1.3$ & $<1.5$ \\
\hline RAR/RXR & TTNPBEQ (ng/L) & $<2000$ & + in yeast assay ${ }^{b}$ & $<400$ & + in yeast assay ${ }^{b}$ & $<90$ & + in yeast assay ${ }^{b}$ \\
\hline Anti-RAR/RXR & BMS493EQ (ng/L) & $<1000$ & + in yeast assay ${ }^{b}$ & $<200$ & + in yeast assay $^{\mathrm{b}}$ & $<50$ & + in yeast assay ${ }^{\mathrm{b}}$ \\
\hline MR & AldoEQ (ng/L) & $<600$ & $\mathrm{n} / \mathrm{a}$ & $<120$ & $\mathrm{n} / \mathrm{a}$ & $<30$ & $\mathrm{n} / \mathrm{a}$ \\
\hline Anti-MR & SpiroEQ (ng/L) & $<3100-3100$ & $\mathrm{n} / \mathrm{a}$ & $<620-910$ & $\mathrm{n} / \mathrm{a}$ & $<160$ & $\mathrm{n} / \mathrm{a}$ \\
\hline
\end{tabular}

areviewed in Leusch et al. (2017); bNo data available for mammalian reporter gene assays, but positive response observed in yeast report gene assays (Inoue et al., 2011)

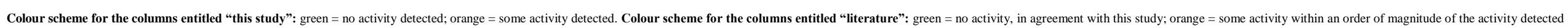
in this study; red $=$ strong bioactivity several orders of magnitude higher than detected in this study.

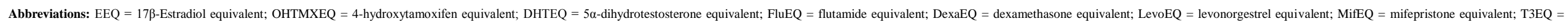
triiodothyronine equivalent; AmiEQ = amiodarone equivalent; TTNPBEQ = TTNPB equivalent; $\mathrm{BMS493EQ} \mathrm{=} \mathrm{BMS493} \mathrm{equivalent;} \mathrm{AldoEQ}$ = aldosterone equivalent; SpiroEQ = spironolactone equivalen 
(2017)). Estrogenic activity in wastewater effluent will vary depending on the treatment processes and wastewater type (Maletz et al., 2013; Valitalo et al., 2016), with surface waters downstream of wastewater discharges often having elevated estrogenicity (Schiliro et al., 2009; Mnif et al., 2012). Wastewater is well known to harbour low ng/L concentrations of various natural and synthetic hormones (Jarosova et al., 2014); while the activity of these compounds in some of the samples using the sensitive in vitro bioassays, they were not detected in the present study because of the high $\mathrm{LOQ}_{\text {chem }}$ associated with limited enrichment of the wastewater samples (see Table S7 for $\mathrm{LOQ}_{\text {chem). }}$ ). Further, Scott et al. (2014) assessed endocrine activity in surface water from 73 sites in Australia with high anti-androgenic and anti-progestagenic activity detected in industrial impacted rivers. In the current study, the endocrine activity observed in Spanish surface water could be attributed to known urban and industrial wastewater discharges.

Very few studies have applied assays indicative of activation and inhibition of MR to water extracts. To our knowledge, the HG5LN-MR assay has only been applied to raw wastewater (Bellet et al., 2012) and surface water passive sampler extracts (Creusot et al., 2014). Antimineralocorticoid activity was detected in both treated wastewater and surface water in the current study, and the significance of this endpoint for environmental waters should be investigated further. The main causative chemicals in surface water in the HG5LN-MR assay were identified as pharmaceuticals dexamethasone, spironolactone and 6-alpha-methylprednisolone (Creusot et al., 2014). In the current study, only dexamethasone was targeted for analysis, but it was not detected above the $\mathrm{LOQ}_{\mathrm{chem}}$.

\subsection{Significance of the detected endocrine activity}

The sensitivity of in vitro bioassays means that effects can be detected even in clean samples after sufficient enrichment. In order to differentiate between an acceptable effect and an unacceptable effect in a bioassay, effect-based trigger values (EBT) for both human and ecological health have been developed in the last few years (Brand et al., 2013; Jarosova et al., 2014; Escher et al., 2015; 
Table 5: Comparison of $\mathrm{BEQ}_{\text {bio }}$ values (ng/L) detected in this study and reported in the literature with available effects based trigger values (EBT) for surface waters (ecological health) and drinking waters (human health).

\begin{tabular}{|c|c|c|c|c|c|c|c|c|c|}
\hline \multirow[b]{2}{*}{ Activity } & \multirow[b]{2}{*}{ Units } & \multirow{2}{*}{$\begin{array}{c}\text { Treated wastewater } \\
\text { and surface water } \\
\text { EBT }\end{array}$} & \multicolumn{2}{|c|}{ Treated wastewater } & \multicolumn{2}{|c|}{ Surface water } & \multirow{2}{*}{$\begin{array}{c}\text { Drinking } \\
\text { water EBT }\end{array}$} & \multicolumn{2}{|c|}{ Drinking water } \\
\hline & & & Current study & Literature & $\begin{array}{c}\text { Current } \\
\text { study }\end{array}$ & Literature & & Current study & Literature \\
\hline ER & EEQ (ng/L) & $\begin{array}{c}0.1-0.4^{\mathrm{at}} \\
0.5^{\mathrm{b}}\end{array}$ & $<0.6-0.78$ & $<0.03-68$ & $<0.1-0.31$ & $<0.01-23$ & $0.2-3.8^{c, d}$ & $<0.03$ & $<0.001-0.08$ \\
\hline $\mathrm{AR}$ & DHTEQ (ng/L) & $\mathbf{n} / \mathbf{a}$ & $<4$ & $<0.1-20$ & $<1$ & $<0.1-12$ & $11^{\mathrm{c}}$ & $<1$ & $<0.01-6.3$ \\
\hline Anti-AR & FluEQ (ng/L) & $25000^{b}$ & $<22000$ & Up to $36000 \dagger$ & $<8900$ & Up to 260000 & $\mathbf{n} / \mathbf{a}$ & $<4400$ & $<41-1000$ \\
\hline GR & DexaEQ (ng/L) & $100^{b}$ & $<120-130 \dagger$ & $<3-188 \dagger$ & $<23-96$ & $<0.4-34$ & $21-150^{c, d}$ & $<5.8$ & $<0.5-13$ \\
\hline PR & LevoEQ (ng/L) & $\mathbf{n} / \mathbf{a}$ & $<2.5$ & $<0.01-7.1$ & $<0.5-1.1$ & $<0.1-8.7$ & $\mathbf{7 3 0}^{\mathrm{c}_{*}}$ & $<0.1$ & $<0.01$ \\
\hline
\end{tabular}

${ }^{a}$ Wastewater effluent EBT calculated for YES, MELN, ER-CALUX, E-SCREEN and MVLN (Jarosova et al., 2014); ${ }^{b}$ Surface water EBT calculated for ER-CALUX, AR-CALUX

(antagonist mode) and GR-CALUX (van der Oost et al., 2017); ${ }^{\circ}$ Drinking water EBT calculated for ER-CALUX, AR-CALUX, GR-CALUX and PR-CALUX (Brand et al., 2013);

${ }^{\mathrm{d}}$ Drinking water and recycled water EBT calculated for ER-GeneBLAzer, ER-CALUX, E-Screen, hERa-HeLa-9903 and GR-CALUX (Escher et al., 2015).

*Calculated from $333 \mathrm{ng} / \mathrm{L}$ Org2058 equivalent in the original reference divided by the relative potency of levonorgestrel in the PR-CALUX of 0.46 compared to Org2058 based on the $\mathrm{EC}_{50}$ values for levonorgestrel from Leusch et al. (2017) and Org2058 from Van der Linden et al. (2008); "treated wastewater; †activity above the surface water EBT, but with a dilution factor of 10 for treated wastewater in the receiving waters assumed $\mathrm{BEQ}_{\text {bio }}$ would likely be below the surface water EBT.

Abbreviations: $\mathrm{EEQ}=17 \beta$-Estradiol equivalent; $\mathrm{DHTEQ}=5 \alpha$-dihydrotestosterone equivalent; FluEQ = flutamide equivalent; DexaEQ = dexamethasone equivalent; LevoEQ = levonorgestrel equivalent; $\mathrm{n} / \mathrm{a}=$ not available. Colour scheme: green $=$ detected activity below available EBT; yellow $=$ activity detected but no EBT available; orange $=$ activity detected $<10 \times$ above the EBT; red $=$ activity detected $>10 \times$ above the EBT; grey $=$ no activity detected and no EBT. 
van der Oost et al., 2017). EBTs have been derived using a number of different approaches, including reading across from existing guideline values and predicted no-effect concentrations. Available treated wastewater, surface water and drinking water EBTs for estrogenic activity, androgenic and anti-androgenic activity, glucocorticoid activity and progestagenic activity are compared with $\mathrm{BEQ}_{\text {bio }}$ values from the current study and the literature in Table 5. EBTs are typically determined for a specific assay, rather than an endpoint; however, the current lack of EBTs meant that all available EBTs for a particular endpoint were considered in the current study, with the assays the EBTs were derived for provided in the footnote to Table 5. While EBTs are useful tools to interpret bioassay results in a risk context, there is still a significant knowledge gap about what constitute a 'safe' effect for many bioassays. As can be seen from Table 5, the availability of EBTs is still rather limited, with very few EBTs available for antagonist activity and none for effects such as thyroid activity or mineralocorticoid activity. Therefore, further work on EBT development is required for a wide range of endocrine endpoints.

While estrogenic activity was low compared to previous studies (Table 4), the detected EEQ values in treated wastewater in France and surface water in Spain were within the same range as the available wastewater effluent and surface water EBTs, suggesting these environmental waters may pose a potential risk to ecosystem health. An EBT for treated wastewater was only available for estrogenic activity, and thus glucocorticoid and anti-androgenic activity in wastewater effluent are compared with available surface water EBTs, which likely over-estimates the risk as the wastewater effluent would be diluted upon discharge in surface waters. The glucocorticoid activity in treated wastewater from Spain exceeded the proposed surface water EBT, though the activity would likely be below the surface water EBT after dilution of the treated wastewater. All environmental samples were below the EBT for anti-androgenic activity in surface water, contrasting with some FluEQ values from the literature for Australian surface waters receiving industrial inputs, which exceeded the EBT by an order of magnitude (Scott et al., 2014). 
All drinking water samples were below the relevant human health EBTs for drinking water from Brand et al. (2013) and Escher et al. (2015), suggesting that the studied drinking waters do not pose a risk to the endocrine health of humans.

\section{Conclusions}

Using a battery of in vitro assays to quantify activity of seven endocrine pathways in treated wastewater, surface water and drinking water from six countries, water samples were found to have very low endocrine activity. Of the examined endocrine pathways, only estrogenic, glucocorticoid, progestagenic and anti-mineralocorticoid activity were detected in treated wastewater and surface water samples, with those positive samples primarily from France and Spain. With the exception of a suspected contaminated sample, none of the drinking water extracts had a response in the bioassays. All drinking water samples were below the available EBTs for estrogenic, androgenic, glucocorticoid and progestagenic activity, suggesting that drinking water does not pose a risk to human endocrine health. Estrogenic activity in some surface and treated wastewater samples however exceeded wastewater and surface water EBTs and undiluted wastewater discharges may pose a risk to aquatic organisms. A limited number of grab samples were analysed in the current study, with a subsequent sampling campaign including more samples and demographics from the regions of collection recommended in order to ascertain the representative nature of the results. The findings of the study provide the first exhaustive international data for these endocrine pathways and are in general agreement with the current scientific consensus on endocrine effects in environmental and drinking waters.

\section{Acknowledgments}

This project, Global Water Research Coalition project \# 2013-05, was funded by PUB (Singapore), the Foundation for Applied Water Research (STOWA), the Joint Research Programme of the Dutch Water Utilities (BTO), Water Research Australia, the Water Technology Center (TZW), the Water 
Research Foundation (WRF) and the Global Water Research Coalition (GWRC). In-kind support was kindly provided by Veolia - VERI, TZW, Suez - CIRSEE, KWR and Griffith University. The South African component of the project was funded by the Water Research Commission. Catherina van Zijl (University of Pretoria), Hannah Simba (University of Pretoria) Christin Kühnert (UFZ), Maria König (UFZ), Jason van de Merwe (Griffith University) and Erik Prochazka (Griffith University) are acknowledged for experimental assistance.

\section{References}

Ait-Aissa, S., Laskowski, S., Laville, N., Porcher, J.M., Brion, F., 2010. Anti-androgenic activities of environmental pesticides in the MDA-kb2 reporter cell line. Toxicol. In Vitro 24, 1979-1985. Bain, P.A., Williams, M., Kumar, A., 2014. Assessment of multiple hormonal activities in wastewwater at different stages of treatment. Environ. Toxicol. Chem. 33, 2297-2307.

Balaguer, P., Boussioux, A.M., Demirpence, E., Nicolas, J.C., 2001. Reporter cell lines are useful tools for monitoring biological activity of nuclear receptor ligands. Luminescence 16, 153-158.

Bellet, V., Hernandez-Raquet, G., Dagnino, S., Seree, L., Pardon, P., Bancon-Montiny, C., Fenet, H., Creusot, N., Ait-Aissa, S., Cavailles, V., Budzinski, H., Antignac, J.P., Balaguer, P., 2012. Occurrence of androgens in sewage treatment plants influents is associated with antagonist activities on other steroid receptors. Water Res. 46, 1912-1922.

Bergman, Å., Heindel, J.J., Jobling, S., Kidd, K.A., Zoeller, R.T. (Eds.), 2013. State of the Science of Endocrine Disrupting Chemicals 2012. United Nations Environment Programme and World Health Organization, Geneva.

Brand, W., de Jongh, C.M., van der Linden, S.C., Mennes, W., Puijker, L.M., van Leeuwen, C.J., van Wezel, A.P., Schriks, M., Heringa, M.B., 2013. Trigger values for investigation of hormonal activity in drinking water and its sources using CALUX bioassays. Environ. Int. 55, 109-118.

Chinathamby, K., Allinson, M., Shiraishi, F., Lopata, A.L., Nugegoda, D., Pettigrove, V., Allinson, G., 2013. Screening for potential effects of endocrine-disrupting chemicals in peri-urban creeks and 
rivers in Melbourne, Australia using mosquitofish and recombinant receptor-reporter gene assays. Environ. Sci. Pollut. Res. 20, 1831-1841.

Conley, J.M., Evans, N., Mash, H., Rosenblum, L., Schenck, K., Glassmeyer, S., Furlong, E.T., Kolpin, D.W., Wilson, V.S., 2017. Comparison of in vitro estrogenic activity and estrogen concentrations in source and treated waters from 25 U.S. drinking water treatment plants. Sci. Total Environ. 579, 1610-1617.

Creusot, N., Ait-Aissa, S., Tapie, N., Pardon, P., Brion, F., Sanchez, W., Thybaud, E., Porcher, J.M., Budzinski, H., 2014. Identification of synthetic steroids in river water downstream from pharmaceutical manufacture discharges based on a bioanalytical approach and passive sampling. Environ. Sci. Technol. 48, 3649-3657.

Devier, M.H., Le Menach, K., Viglino, L., Di Gioia, L., Lachassagne, P., Budzinski, H., 2013. Ultra-trace analysis of hormones, pharmaceutical substances, alkylphenols and phthalates in two French natural mineral waters. Sci. Total Environ. 443, 621-632.

Eggen, R.I.L., Hollender, J., Joss, A., Scharer, M., Stamm, C., 2014. Reducing the discharge of micropollutants in the aquatic environment: The benefits of upgrading wastewater treatment plants. Environ. Sci. Technol. 48, 7683-7689.

Escher, B.I., Leusch, F.D.L., 2012. Bioanalytical tools in water quality assessment. IWA Publishing, London.

Escher, B.I., Neale, P.A., Leusch, F.D.L., 2015. Effect-based trigger values for in vitro bioassays: Reading across from existing water quality guideline values. Water Res. 81, 137-148.

Freitas, J., Cano, P., Craig-Veit, C., Goodson, M.L., Furlow, J.D., Murk, A.J., 2011. Detection of thyroid hormone receptor disruptors by a novel stable in vitro reporter gene assay. Toxicol. In Vitro $25,257-266$.

Harries, J.E., Sheahan, D.A., Jobling, S., Matthiessen, P., Neall, P., Routledge, E.J., Rycroft, R., Sumpter, J.P., Tylor, T., 1996. A survey of estrogenic activity in United Kingdom inland waters. Environ. Toxicol. Chem. 15, 1993-2002. 
Heeb, F., Singer, H., Pernet-Coudrier, B., Qi, W.X., Liu, H.J., Longree, P., Muller, B., Berg, M., 2012. Organic micropollutants in rivers downstream of the megacity Beijing: Sources and mass fluxes in a large-scale wastewater irrigation system. Environ. Sci. Technol. 46, 8680-8688. Inoue, D., Nakama, K., Sawada, K., Watanabe, T., Matsui, H., Sei, K., Nakanishi, T., Ike, M., 2011. Screening of agonistic activities against four nuclear receptors in wastewater treatment plants in Japan using a yeast two-hybrid assay. J. Environ. Sci. 23, 125-132.

Jarosova, B., Blaha, L., Giesy, J.P., Hilscherova, K., 2014. What level of estrogenic activity determined by in vitro assays in municipal waste waters can be considered as safe? Environ. Int. 64, 98-109.

König, M., Escher, B.I., Neale, P.A., Krauss, M., Hilscherova, K., Novak, J., Teodorovic, I., Schulze, T., Seidensticker, S., Hashmi, M.A.K., Ahlheim, J., Brack, W., 2017. Impact of untreated wastewater on a major European river evaluated with a combination of in vitro bioassays and chemical analysis. Environ. Pollut. 220, 1220-1230.

Leusch, F.D.L., Neale, P.A., Hebert, A., Scheurer, M., Schriks, M.C.M., 2017. Analysis of the sensitivity of in vitro bioassays for androgenic, progestagenic, glucocorticoid, thyroid and estrogenic activity: Suitability for drinking and environmental waters. Environ. Int. 99, 120-130. Maletz, S., Floehr, T., Beier, S., Klumper, C., Brouwer, A., Behnisch, P., Higley, E., Giesy, J.P., Hecker, M., Gebhardt, W., Linnemann, V., Pinnekamp, J., Hollert, H., 2013. In vitro characterization of the effectiveness of enhanced sewage treatment processes to eliminate endocrine activity of hospital effluents. Water Res. 47, 1545-1557.

Mnif, W., Zidi, I., Hassine, A.I.H., Gomez, E., Bartegi, A., Roig, B., Balaguer, P., 2012. Monitoring endocrine disrupter compounds in the Tunisian Hamdoun River using in vitro bioassays. Soil \& Sediment Contamination 21, 815-830.

Neale, P.A., Brack, W., Ait-Aissa, S., Busch, W., Hollender, J., Krauss, M., Maillot-Maréchal, E., Munz, N.A., Schlichting, R., Schulze, T., Vogler, B., Escher, B.I., 2018. Solid-phase extraction as 
sample preparation of water samples for cell-based and other in vitro bioassays. Environmental Science: Processes \& Impacts In Press 10.1039/C7EM00555E.

Piersma, A.H., Bosgra, S., van Duursen, M.B.M., Hermsen, S.A.B., Jonker, L.R.A., Kroese, E.D., van der Linden, S.C., Man, H., Roelofs, M.J.E., Schulpen, S.H.W., Schwarz, M., Uibel, F., van Vugt-Lussenburg, B.M.A., Westerhout, J., Wolterbeek, A.P.M., van der Burg, B., 2013. Evaluation of an alternative in vitro test battery for detecting reproductive toxicants. Reproductive Toxicology $38,53-64$.

Purdom, C.E., Hardiman, P.A., Bye, V.V.J., Eno, N.C., Tyler, C.R., Sumpter, J.P., 1994. Estrogenic effects of effluents from sewage treatment works. Chem. Ecol. 8, 275-285.

Rutishauser, B.V., Pesonen, M., Escher, B.I., Ackermann, G.E., Aerni, H.R., Suter, M.J.F., Eggen, R.I.L., 2004. Comparative analysis of estrogenic activity in sewage treatment plant effluents involving three in vitro assays and chemical analysis of steroids. Environ. Toxicol. Chem. 23, 857864.

Schiliro, T., Pignata, C., Rovere, R., Fea, E., Gilli, G., 2009. The endocrine disrupting activity of surface waters and of wastewater treatment plant effluents in relation to chlorination. Chemosphere $75,335-340$.

Scott, P.D., Bartkow, M., Blockwell, S.J., Coleman, H.M., Khan, S.J., Lim, R., McDonald, J.A., Nice, H., Nugegoda, D., Pettigrove, V., Tremblay, L.A., Warne, M.S.J., Leusch, F.D.L., 2014. An assessment of endocrine activity in Australian rivers using chemical and in vitro analyses. Environ. Sci. Pollut. Res. 21, 12951-12967.

Sohoni, P., Sumpter, J.P., 1998. Several environmental oestrogens are also anti-androgens. J. Endocrinol. 158, 327-339.

Suzuki, G., Sato, K., Isobe, T., Takigami, H., Brouwer, A., Nakayama, K., 2015. Detection of glucocorticoid receptor agonists in effluents from sewage treatment plants in Japan. Sci. Total Environ. 527, 328-334. 
Valitalo, P., Perkola, N., Seiler, T.B., Sillanpaa, M., Kuckelkorn, J., Mikola, A., Hollert, H., Schultz, E., 2016. Estrogenic activity in Finnish municipal wastewater effluents. Water Res. 88, 740-749.

Van der Linden, S.C., Heringa, M.B., Man, H.Y., Sonneveld, E., Puijker, L.M., Brouwer, A., Van der Burg, B., 2008. Detection of multiple hormonal activities in wastewater effluents and surface water, using a panel of steroid receptor CALUX bioassays. Environ. Sci. Technol. 42, 5814-5820. van der Oost, R., Sileno, G., Suárez-Muñoz, M., Nguyen, M.T., Besselink, H., Brouwer, A., 2017. SIMONI (smart integrated monitoring) as a novel bioanalytical strategy for water quality assessment: Part I--model design and effect-based trigger values. Environ. Toxicol. Chem. 36, 2385-2399.

Wernersson, A.-S., Carere, M., Maggi, C., Tusil, P., Soldan, P., James, A., Sanchez, W., Dulio, V., Broeg, K., Reifferscheid, G., Buchinger, S., Maas, H., Van Der Grinten, E., O’Toole, S., Ausili, A., Manfra, L., Marziali, L., Polesello, S., Lacchetti, I., Mancini, L., Lilja, K., Linderoth, M., Lundeberg, T., Fjällborg, B., Porsbring, T., Larsson, D.J., Bengtsson-Palme, J., Förlin, L., Kienle, C., Kunz, P., Vermeirssen, E., Werner, I., Robinson, C.D., Lyons, B., Katsiadaki, I., Whalley, C., den Haan, K., Messiaen, M., Clayton, H., Lettieri, T., Carvalho, R.N., Gawlik, B.M., Hollert, H., Di Paolo, C., Brack, W., Kammann, U., Kase, R., 2015. The European technical report on aquatic effect-based monitoring tools under the water framework directive. Environ. Sci. Eur. 27, 1-11. 